\title{
PENGGUNAAN TEPUNG JEROAN IKAN CAKALANG TERHADAP PRODUKSI TELUR BURUNG PUYUH
}

\author{
Utilization of Skipjack Innards Flour as Substitute of Fish Meal \\ for Quail Egg Production (Coturnix-Coturnix Japanica) \\ *Andrian Nusi ${ }^{1}$, Srisukmawati Zainudin ${ }^{2}$, Syahruddin ${ }^{2}$, Fahria Datau ${ }^{2}$ \\ ${ }^{1)}$ Animal Husbandry Departement, Faculty of Agriculture, Gorontalo State University \\ ${ }^{2}$ Alumni of Animal Husbandry Departement, Faculty of Agriculture, Gorontalo State University \\ Jl. Prof. Dr. Ing B.J Habibie, Moutong, Kab. Bone Bolango, 96119 \\ Corresponding Authors: E-mail: nusiandrian98@gmail.com
}

\begin{abstract}
The purpose of the study was to determine the effect of giving skipjack viscera flour as a substitute for fish meal in the ration on the production of quail eggs. This research was conducted in SeptemberOctober 2020, in Boidu Village, North Bulango District, Bone Bolango Regency, Gorontalo Province. The study used a completely randomized design (CRD) with 5 treatments and 4 replications. A total of 160 quails aged 47 days. The results showed that the provision of skipjack offal flour as a substitute for fish meal in the ration did not have a significant effect $(\mathrm{P}>0.05)$ on the observed variables. Skipjack viscera flour can be used in quail rations as much as $12 \%$ in the ration.
\end{abstract}

Keyword: Egg production, Quail, Skipjack viscera,

\begin{abstract}
ABSTRAK
Tujuan penelitian adalah untuk mengetahui pengaruh pemberian tepung jeroan cakalang sebagai substitusi tepung ikan dalam ransum terhadap produksi telur puyuh. Penelitian ini dilaksanakan pada bulan September-Oktober 2020, di Desa Boidu, Kecamatan Bulango Utara, Kabupaten Bone Bolango, Provinsi Gorontalo. Penelitian menggunakan Rancangan Acak Lengkap (RAL) dengan 5 perlakuan dan 4 ulangan. Sebanyak 160 ekor puyuh berumur 47 hari. Hasil penelitian menunjukkan bahwa pemberian tepung jeroan cakalang sebagai pengganti tepung ikan dalam ransum tidak memberikan pengaruh yang signifikan $(P>0,05)$ terhadap variabel yang diamati. Tepung jeroan cakalang dapat digunakan dalam ransum burung puyuh sebanyak $12 \%$ dalam ransum.
\end{abstract}

Kata kunci: Burung Puyuh, Jeroan Ikan Cakalang, Produksi telur

APA Citation Style

Nusi A., Zainudin S., Syahruddin, dan Datau F. 2021. Penggunaan Tepung Jeroan Ikan Cakalang Terhadap Produksi Telur Burung Puyuh. Jambura Journal odf Animal Science 4(1) 53-59 


\section{PENDAHULUAN}

Ikan Cakalang merupakan ikan pelagis, termasuk jenis ikan tuna dalam famili Scombridae, species Katsuwonus pelamis. Jenis ikan ini menjadi target tangkap utama nelayan karena harganya yang stabil. Produksi ikan ini sangat melimpah di Provinsi Gorontalo

Ternak burung puyuh (Coturnixcoturnix japonica) saat ini menjadi salah satu sumber pendapatan masyarakat. Budidaya burung puyuh merupakan usaha yang cocok untuk masyarakat kecil karena modal yang dibutuhkan untuk beternak tidak sebesar modal untuk beternak ayam broiler ataupun ayam petelur, selain itu tidak memerlukan waktu lama dan lahan yang luas.

Peningkatan produksi telur dan daging puyuh tidak lepas dari genetic dan lingkungan. Factor lingkungan diantaranya perkandangan dan makanan. Pengaturan kepadatan kandang tidak meberikan pengaruh yang siknifikan terhadap produksi telur (Ali et al., 2019), sedangkan uji tepung jeroan ikan cakalang hingga taraf $12 \%$ dalam ransum sebagai subtitusi tepung ikan tidak memberikan dampak terhadap pertumbuhan dari burung puyuh. (Dauhi, 2021).

Tepung ikan merupakan salah satu bahan pakan utama penyusun ransum burung puyuh, karena mempunyai kandungan yang sangat dibutuhkan oleh ternak yaitu sebagai sumber protein dalam ransum unggas dan hampir semua formula ransum unggas menggunakan tepung ikan sebagai sumber protein, namun harga tepung ikan sangat mahal. Jeroan ikan cakalang merupakan limbah dari hasil tangkapan ikan cakalang (Katsuwonus pelamis L) dapat digunakan sebagai bahan pakan sumber protein. Melalui proses pengolahan secara mekanis, maka kandungan nutrien limbah ikan cakalang tersebut dapat dipertahankan sehingga masih dapat dimanfaatkan dalam ransum ternak unggas sebagai substitusi tepung ikan. Hasil analisis yang telah dilakukan, jeroan ikan cakalang memiliki kandungan nutrien sebagai berikut; protein kasar 72,71\%; lemak kasar 10,22\%; serat kasar 1,84\%; kadar abu 8,48\%; kadar air 2,96\%; Ca 1,37\%; P 1,72\%; Gross energy 4768,46\%;dan nilai $\mathrm{pH}$ sebesar 5,29. (Dauhi, dkk, 2021). Belum banyak informasi tentang penggunaan jeroan ikan cakalang dalam ransum terutama peningkatan produksi telur burung puyuh, hal inilah yang membuat penulis tertarik melakukan penelitian dengan judul pemberian jeroan ikan cakalang sebagai substitusi tepung ikan dalam ransum terhadap produksi telur burung puyuh (Coturnix-coturnix japonica). Pemanfaatan jeroan ikan cakalang sebagai alternatif substitusi tepung ikan dalam ransum yang secara langsung dapat menekan biaya produksi dalam usaha pemeliharaan burung puyuh. Tujuan penelitian untuk mengetahui pengaruh pemberian tepung jeroan ikan cakalang sebagai pengganti tepung ikan dalam ransum terhadap produksi telur burung puyuh (Coturnixcoturnix japonica)

\section{METODE PENELITIAN}

Penelitian telah dilakukan pada bulan September sampai Oktober 2020, di Desa Boidu Kecamatan Bulango Utara, Kabupaten Bone Bolango, Provinsi Gorontalo. Penelitian ini menggunakan burung puyuh (Coturnix-coturnix japonica) sebagai ternak percobaan sebanyak 160 ekor yang berumur 6 minggu, yang dipelihara dalam kandang battery sebanyak 20 unit kandang perlakuan, setiap unit kandang berisi 8 ekor burung puyuh.

Ransum yang diberikan terdiri dari bahan pakan jagung kuning, tepung jeroan ikan cakalang yang dikukus, tepung ikan, bungkil kedelai giling, premix dan dedak halus. Jeroan ikan cakalang dibuat dalam bentuk tepung untuk menggati tepung ikan didalam ransum, penggantian ini dilakukan secara bertahap. Komposisi dan kandungan ransum dapat dilihat pada tabel 1. 
Tabel 1. Komposisi dan kandungan nutrisi ransum percobaan

\begin{tabular}{lrrrrr}
\multicolumn{1}{c}{ Nama Bahan } & \multicolumn{5}{c}{ Perlakuan } \\
P0 & \multicolumn{1}{c}{ P1 } & P2 & P3 & \multicolumn{1}{c}{ P4 } \\
\hline Jagung Giling & 51 & 51 & 51 & 51 & 51 \\
Dedak Halus & 22 & 22 & 22 & 22 & 22 \\
Tepung Ikan & 12 & 9 & 6 & 3 & 0 \\
Tepung Ikan Jeroan Cakalang & 0 & 3 & 6 & 9 & 12 \\
Bungkil Kedelei & 13 & 13 & 13 & 13 & 13 \\
Top mix & 2 & 2 & 2 & 2 & 2 \\
\hline Jumlah & 100 & 100 & 100 & 100 & 100 \\
\hline Komposisi Nutrisi & P0 & P1 & P2 & P3 & P4 \\
\hline Protein Kasar (\%) & 20,70 & 20,75 & 20,80 & 20,84 & 20,90 \\
Lemak Kasar (\%) & 6,90 & 6,91 & 6,93 & 6,94 & 6,96 \\
Serat Kasar (\%) & 5,65 & 5,55 & 5,45 & 5,35 & 5,25 \\
Kalsium (\%) & 3,08 & 2,92 & 2,77 & 2,62 & 2,47 \\
Fosfor (\%) & 1,154 & 1,13 & 1,14 & 1,14 & 1,13 \\
Energi Metabolisme (Kkal/Kg) & $2.893,80$ & $2.915,97$ & $2.934,55$ & $2.953,13$ & $2.971,72$ \\
Harga (Rp) & 3.795 & 3.645 & 3.435 & 3.255 & 3.075 \\
\hline
\end{tabular}

Jeroan ikan cakalang yang digunakan diperoleh dari tempat penampungan ikan (TPI) Propinsi Gorontalo dan tempat pengolahan ikan cakalang fufu. Proses pembuatan tepung jeroan ikan cakalang mengikuti petunjuk Dauhi,dkk (2021). Penelitian ini menggunakan Rancangan Acak Lengkap (RAL) terdiri dari 5 perlakuan dan 4 ulangan, setiap unit percobaan digunakan 8 ekor burung puyuh. Ransum perlakuan yang digunaka, terdiri dari :

$\mathrm{P0}=$ Ransum tanpa tepung jeroan ikan cakalang

P1 = Ransum yang diberi tepung ikan 9\% dan 3\% tepung jeroan ikan cakalang

$\mathrm{P} 2=$ Ransum yang diberi tepung ikan 6\% dan $6 \%$ tepung jeroan ikan cakalang

P3 = Ransum yang diberi tepung ikan 3\% dan $9 \%$ tepung jeroan ikan cakalang

$\mathrm{P} 4=$ Ransum yang diberi $12 \%$ tepung jeroan ikan cakalang

Parameter yang diamati dalam penelitian, adalah konsumsi ransum, produksi telur, konversi ransum, dan ketebalan kerabang telur burung puyuh. Pengambilan data dilakukan selama 4 minggu, yang dimulai dari burung puyuh berumur 6-10 minggu. Jumlah konsumsi dihitung berdasarkan jumlah ransum yang diberikan setiap hari kemudian dikurangi dengan ransum yang tersisa setelah itu dibagi dengan jumlah ternak satuan g/ekor/hari (Akbar dan Muhammad, 2017; Moyiu, 2020; Ismai, dkk 2021) Produksi telur, dihitung setiap hari dengan cara jumlah telur dalam satu hari dibagi dengan jumlah ternak yang kemudian dikali 100\% (Triyanto, 2007). Konversi ransum dihitung dengan membagi jumlah ransum yang dikonsumsi dengan produlksi telur setiap minggu,dengan satuan g/ekor/hari (Akbar dan Muhammad, 2017). dan Tebal kerabang dihitung dengan Pengukuran tebal kerabang dilakukan pada baguan ujung tumpul, dan ujung lancip telur kemudian dibuat rata-rata (Sulaiman dkk., 2018 ). Data hasil pengamatan dianalisis menggunakan Analysis Of Variance (Anova) sesuai petunjuk (Pakaya \& Zainudin, 2019).

\section{HASIL DAN PEMBAHASAN}

\section{Konsumsi ransum}

Konsumsi

ransum merupakan jumlah pakan yang dikonsumsi oleh burung puyuh dalam sehari. Rata-rata konsumsi ransum burung puyuh yang diberikan tepung jeroan ikan cakalang hasil sebagai subtitusi tepung ikan dalam ransum selama penelitian dapat dilihat pada Gambar 1 


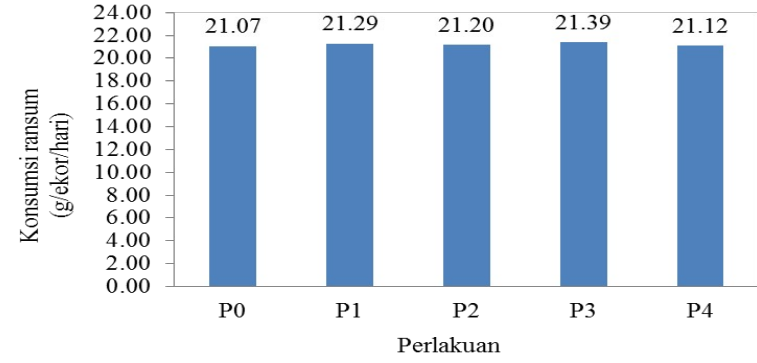

Gambar 1. Grafik rata-rata konsumsi ransum burung puyuh

Berdasarkan Gambar 1. diketahui bahwa, jumlah konsumsi ransum burung puyuh yang diberi tepung jeroan ikan cakalang lebih besar dibanding perlakuan P0 (kontrol). Diduga bahwa tepung jeroan ikan cakalang memiliki tekstur sangat baik dan bau yang harum (bau khas), sehingga dapat meningkatkan palatabilitas ransum sebagaimana Nuraini dkk., (2012). Hasil Analysis of variance (Anova) menunjukan bahwa, konsumsi ransum burung puyuh pada setiap perlakuan tepung jeroan ikan cakalang dalam ransum relatif sama atau tidak berbeda dengan perlakuan P0 (kontrol).

Rata-rata konsumsi ransum burung puyuh umur 6-10 minggu, berkisar antara 21,07-21,39 g/ekor/hari. Jumlah konsumsi ransum tersebut masih dalam kisaran normal sebagaimana Achmanu, dkk., (2011) yang menyatakan bahwa, konsumsi pakan normal burung puyuh adalah 17,50-29,63 g/ekor/hari.

Konsumsi ransum yang relatif sama tersebut, diduga dipengaruhi oleh kandungan nutrisi yang relatif sama pada setiap ransum yang diberikan, sebagaimana Widya (2017) yang melaporkan bahwa, kandungan zat makanan pada ransum yang diberikan relatif sama, sehingga konsumsi ransum tiap perlakuan tidak jauh berbeda.

\section{Produksi Telur}

Prodiksi telur merupakan jumlah telur yang di hasilkan dalam sehari atau dalam kurun waktu tertentu (hari/minggu/bulan/tahun). Rata-rata produksi telur burung puyuh yang menggunakan tepung jeroan ikan cakalang sebagai bahan pakan subtitusi tepung ikan dalam ransum selama penelitian dapat dilihat pada Gambar 2.

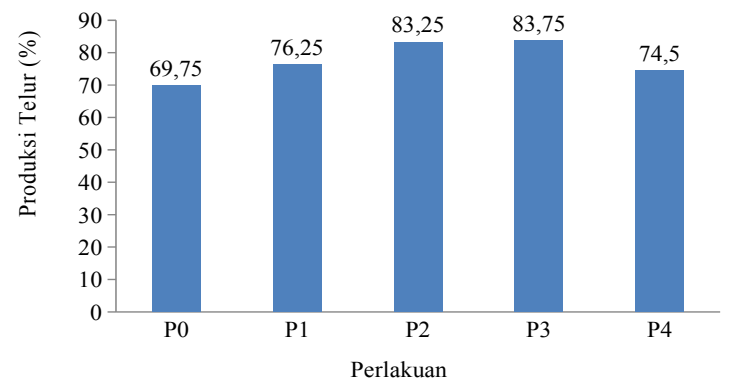

Gambar 2. Grafik Rata-rata produksi telur burung puyuh

Hasil Anova menunjukkan bahwa pemberian tepung jeroan ikan cakalang sebagai substitusi tepung ikan dalam ransum tidak memberikan pengaruh yang nyata $(\mathrm{P}>0,05)$ terhadap persentase produksi telur burung puyuh selama periode pemeliharaan 6-10 minggu. Persentase produksi telur yang relatif sama diduga dipengaruhi oleh konsumsi ransum yang relatif sama (tidak berbeda nyata) diantara perlakuan. Hasil penelitian ini sejalan dengan Widya (2017) yang 
melaporkan bahwa, konsumsi ransum yang hampir sama tidak mempengaruhi produksi telur burung puyuh. Diduga pula bahwa produksi telur burung puyuh dalam penelitian ini masih berjalan normal, hal ini dipengaruhi oleh kandungan nutrien dari ransum percobaan (ransum yang mengandung tepung jeroan ikan cakalang) memberikan intake nutrien yang cukup menyebabkan ternak burung puyuh dalam kondisi sehat, sehingga pembentukan dan produksi telur relatif sama dengan perlakuan P0 (kontrol).

$$
\text { Grafik pada Gambar 2, }
$$
memperlihatkan pula bahwa rerata persentase produksi telur burung puyuh yang diberi tepung jeroan ikan cakalang sebagai substitusi tepung ikan dalam ransum selama penelitian berkisar $69,75 \%$ $83,75 \%$. Persentase produksi telur burung puyuh dalam penelitian ini lebih tinggi dibandingkan hasil yang dilaporkan oleh Eishu dkk., (2005) bahwa, rataan produksi telur burung puyuh berumur 6-10 minggu sebesar 51,3\%. Menurut Setyawan dkk., (2012), jika manajemen pemeliharaan dan pemberian pakan dilakukan dengan baik dan benar, produksi telur burung puyuh dapat mencapai puncak produksi sebesar $96 \%$

\section{Konversi Ransum}

Rata-rata nilai konversi ransum burung puyuh yang menggunakan tepung jeroan ikan cakalang sebagai bahan pakan subtitusi tepung ikan dalam ransum dapat dilihat pada Gambar 3.

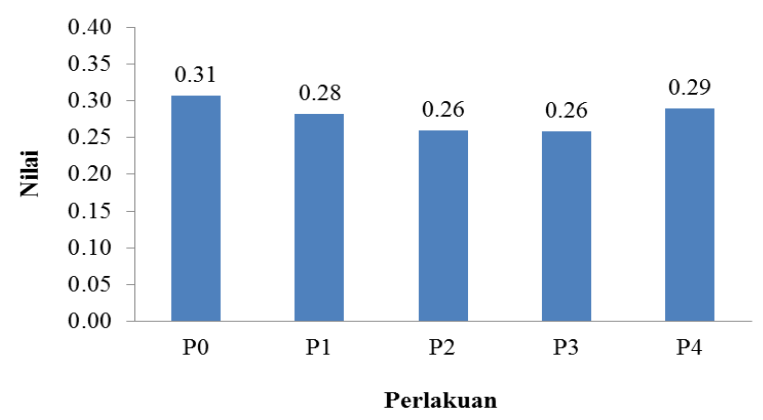

Gambar 3. Grafik Rataan Konversi Pakan burung puyuh

Hasil penelitian, menunjukkan bahwa pemberian tepung jeroan ikan cakalang sebagai subtitusi tepung ikan tidak memberikan pengaruh nyata $(\mathrm{P}>0.05)$ terhadap nilai konversi ransum burung puyuh umur 6-10 minggu. Hal ini dapat berarti bahwa nilai konversi ransum perlakuan P1, P2, P3 dan P4 relatif sama atau tidak memiliki perbedaan dengan perlakuan P0 (kontrol). Berdasarkan Gambar 3. menunjukkan bahwa nilai konversi ransum burung 6-10 minggu berkisar antara 0.31-0,26. Hal ini dipengaruhi oleh konsumsi pakan dan produksi telur burung puyuh yang sama setiap perlakuan. Tidak berbedanya angka konvers di sebabkan jumlah konsumsi dan produksi telur yang sama setiap perlakuan. Hasil ini menjelaskan bahwa factor produksi bukan saja dipengaruhi oleh factor pakan akan tetapi dipengaruhi oleh genetic ternak. Salah satu yang mempengaruhi produktivitas ternak unggas adalah faktor genetic dan lingkungan (Dako dkk, 2019)

Puspita (2008) yang menyatakan bahwa konversi ransum erat kaitannya dengan konsumsi ransum dan produksi telur. indikator penentu produktifitas telur banyak dipengaruhi oleh kandungan nutrisi pakan, konsumsi pakan dan umur.

\section{Tebal Kerabang Telur Burung Puyuh}

Tebal kerabang telur sangat penting dalam hubungannya dengan ketahanan telur dan melindungi kerusakan telur secara fisik. Rata-rata nilai tebal kerabang dapat dilihat pada Gambar 4. 


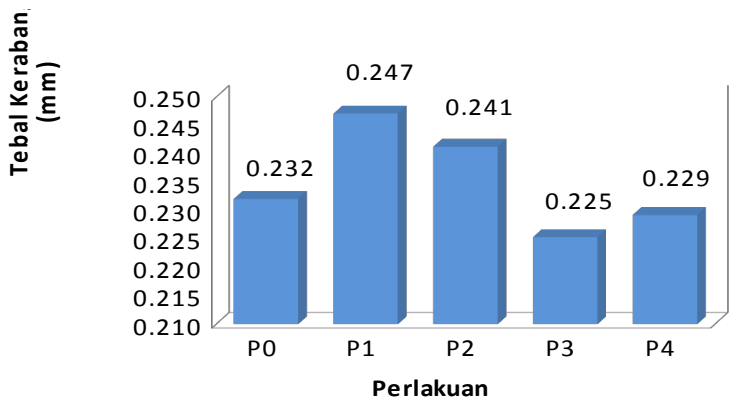

Gambar 4. Grafik nilai tebal kerabang telur

Hasil Analysis of Variance (ANOVA) menunjukkan bahwa penggunaan tepung jeroan ikan cakalang sebagai subtitusi tepung ikan dalam ransum tidak memberikan pengaruh yang nyata $(\mathrm{P}>0.05)$ terhadap ketebalan kerabang telur burung puyuh umur 6-10 minggu. Berdasarkan Gambar 4. menunjukkan bahwa nilai kerabang telur burung puyuh hasil penelitian berkisar $0.232-0.247 \mathrm{~mm}$ atau jika dibulatkan berkisar 0.23-0.25 menunjukkan hasil yang baik dan tahan terhadap benturan, sebagaimana Sudarajat dkk., (2014) menyatakan bahwa tebal kerabang telur puyuh menunjukkan kualitas ketahanan telur terhadap benturan dengan tebal normal sekitar $0.22 \mathrm{~mm}$. Sudaryani (2006) menyatakan bahwa tebal kerabang telur mempunyai hubungan yang berbanding terbalik dengan suhu lingkungan, suhu yang tinggi akan mengurangi kekuatan dan ketebalan kerabang telur.

\section{DAFTAR PUSTAKA}

Achmanu, Muharlien dan Salaby. 2011. Pengaruh lantai kandang (rapat dan renggang) dan imbangan jantan betina terhadap konsumsi pakan, bobot telur, konversi pakan dan tebal kerabang pada burung puyuh. J. Ternak Tropika. 12(2):1-14.

Akbar, M. dan M, E. Hari. 2017. Pengaruh Pemberian Sari Kunyit (curcuma longa L) dan Temulawak (curcumaxanthorriza roxb) dalam Air Minum Terhadap Performa Burung

\section{KESIMPULAN}

Berdasarkan hasil penelitian menunjukkan bahwa, penggunaan jeroan ikan cakalang sebagai subtitusi tepung ikan dalam ransum burung puyuh (Coturnixcoturnix japonica) dengan taraf 3\%, 6\%, 9\% dan $12 \%$ dalam ransum tidak berbeda nyata namun bisa dilihat pada grafik memberikan respon yang baik terhadap konsumsi ransum, produksi telurn, konversi ransum dan tebal kerabang telur.

\section{UCAPAN TERIMAKASIH}

Ucapan terima kasih disampaikan kepada Dekan Fakultas Pertanian, Atas pembiayaan Penelitian, melalui SKIM Penelitian Kolaboratif Tahun Anggaran 2021, Dan pemilik usaha peternakan burung puyuh Keluarga Bapak Rusli Dauhi di Desa Boidu Kecamatan Bulango Utara, Kabupaten Bone Bolango, Provinsi Gorontalo yang telah memberikan izin untuk melakukan penelitian di lokasi tersebut.

Puyuh Jantan. Jurnal Fillia Cendekia. 2(2):8-16

Ali, L., Gubali, S. I., \& Saleh, E. J. (2019). PENAMPILAN PRODUKSI TELUR BURUNG PUYUH PADA TINGKAT KEPADATAN KANDANG YANG BERBEDa. Jambura Journal of Animal Science, $2(1)$. https://doi.org/10.35900/jjas.v2i1.234 6

Dako, S. (2019). Crossbreding Between Native Chiken And Leghorn Chiken 
Strain Isa Brown. Jurnal Peternakan, 16(1), 1-9.

Dako, S., Laya, N. K., Ilham, F., \& Yusuf, F. M. (2019). Manajemen pembibitan Ternak (Vol. 1). CV. ATHRA SAMUDRA

Ismail, Y., Syahruddin, S., \& Zainudin, S. (2021). PERFORMA AYAM KAMPUNG SUPER YANG DIBERI TEPUNG USUS AYAM SEBAGAI SUBTITUSI TEPUNG IKAN. Jambura Journal of Animal Science, 3(2), 120-128.

Moyiu, F. (2020). SIFAT KUANTITATIF BURUNG WERIS (GALLIRALLUS PHILIPPENSIS) JANTAN DAN BETINA. Jambura Journal of Animal Science, 2(2), 54-61. https://doi.org/10.35900/jjas.v2i2.222 2

Nuraini, Sabrina dan S.A. Latif. 2012. Penampilan dan kualitas telur puyuh yang diberi pakan mengandung produk fermentasi dengan Neurospora crassa. Jurnal Peternakan Indonesia 14 (2),Juni 2012. ISSN 1907-1760

Pakaya, S. A., \& Zainudin, S. (2019). PERFORMA AYAM KAMPUNG SUPER YANG DI BERI LEVEL PENAMBAHAN TEPUNG KULIT KAKAO (Theobroma cacao, L.) FERMENTASI DALAM RANSUM. Jambura Journal of Animal Science, 1(2). https://doi.org/10.35900/jjas.v1i2.260 3

Puspita. R. D. (2008). Usulan Perancangan Perbaikan Dengan Metode Six Sigma Untuk Peningkatan Kualitas Produk Sarung "Gajah Duduk" di PT Pismatex Textile Industry. Tugas Akhir S1 Teknik Industri Institut Teknologi Telkom, Bandung
Setiawan D. 2012. Performa Produksi Burung Puyuh (Coturnix coturnix japonica) pada Perbandingan Jantan dan Betina yang Berbeda. skripsi. Fakultas Peternakan Institut Pertanian Bogor

Sudaryani, Titik, Santosa H .2006. Pembibitan Ayam Ras. PT. Penebar Swadaya, Jakarta

Sudrajat D, Kardaya D, Dihansih E, Puteri SFS. 2014. Performa produksi telur burung puyuh yang diberi ransum mengandung kromium organik. JITV 19(4): 257-262

Sulaiman, A., Rahmatullah, S.N. 2011. Karakteristik Eksterior, Produksi dan Kualitas Telur Itik Alabio (Anas plathynchos Borneo)di Sentra Peternakan Itik Kalimantan Selatan. Fakultas Pertanian Universitas Lambung Mangkurat. Kalimantan Selatan

Dauhi, Taufik, Srisukmawati Zainudin, and Syukri I. Gubali. "Penampilan Burung Puyuh (Coturnix-coturnix japonica) yang diberi Tepung Jeroan Ikan Cakalang sebagai Pengganti Tepung Ikan." Jambura Journal of Animal Science 3.2 (2021): 105-112.

Triyanto. 2007. Performa Produksi Burung Puyuh (Coturnix-coturnix Japonica) Periode Produksi Umur 6-13 Minggu. Skripsi. Fakulats Peternakan Institute Pertanian Bogor

Widya p. 2017. Nutrisi dan Menejemen pakan burung puyuh. Airlangga university press. Surabaya. 